\title{
PENGARUH PENERAPAN METODE PEMBELAJARAN FISIKA BERBASIS EKSPERIMEN VIRTUAL TERHADAP MOTIVASI DAN HASIL BELAJAR FISIKA SISWA KELAS X MAN 2 MATARAM TAHUN AJARAN 2014/2015
}

\author{
Muthmainnah, Joni Rokhmat, Jannatin ‘Ardhuha \\ Program Studi Pendidikan Fisika. \\ Universitas Mataram. \\ Mataram, Indonesia. \\ Email : iinmuth.muthmainnah@gmail.com
}

\begin{abstract}
This research aimed to know the effect of physics learning method with virtual experiment on motivation and physics learning result of $10^{\text {th }}$ grade students of MAN 2 Mataram in academic year of 2014/2015. This experiment employed posttest only control group design. Samples were taken by using purposive sampling technique. $X 3$ class was chosen as experiment class and X 5 as control class. The result showed that motivation and learning results of experiment class students mean score were 78.75 and 78.20 , respectively, while the motivation and learning results of control class students mean score were 68.29 and 64.67. The motivation data of both classes were homogeneous. On the other hand, the learning results of both classes were not homogeneous. Both data were analyzed by using $t$-test. It was obtained that $t_{\text {count }}$ score were 6.10 and 5.18 for motivation and learning results, respectively, with tabel score were 1.99 and 2.04 at significant rate of $5 \%$. The $t_{\text {count }}$ was greater than $t_{\text {tabel, }}$ which meant there was difference between the students who were got the physics learning method with virtual experiment and the conventional one. It can be concluded that physics learning method with virtual experiment affected motivation and physics learning results.
\end{abstract}

Keywords: Virtual experiment method, learning motivation, physics learning results.

\section{PENDAHULUAN}

Pada hakikatnya, Ilmu Pengetahuan Alam (IPA) merupakan proses dan produk tentang pengkajian gejala alam yang meliputi gejala fisika, kimia, dan biologi. Karenanya, penguasaan IPA khususnya cabang fisika tidak cukup hanya dengan cara belajar dari buku atau sekedar mendengarkan penjelasan dari pihak lain. Mempelajari fisika berarti memecahkan serta menemukan mengapa dan bagaimana peristiwa itu terjadi (Lesmono, Wahyuni, \& Fitriya, 2012). Oleh karena itu, pembelajaran fisika membutuhkan suatu metode yang dapat membuat siswa lebih aktif dan mampu melatih siswa menemukan pengetahuannya secara mandiri. Cukup banyak metode dan media pembelajaran yang dapat dimanfaatkan oleh guru untuk menunjang pembelajaran fisika agar siswa ikut berperan aktif dalam proses pembelajaran tersebut.

Berdasarkan hasil observasi di MAN 2 Mataram, peneliti menemukan bahwa hasil belajar fisika siswa masih di bawah Kriteria Ketuntasan Minimum (KKM) yang ditetapkan sekolah, yaitu 75 . Hal ini ditunjukkan dari hasil nilai rata-rata ujian akhir semester ganjil siswa kelas X 1 sampai X 5 pada mata pelajaran fisika tahun ajaran 2014/2015 yang berkisar antara 62,50 sampai dengan 67,64.

Berdasarkan hasil observasi tersebut, diketahui bahwa rendahnya hasil belajar fisika siswa ini dipengaruhi oleh motivasi belajar siswa rendah. Rendahnya motivasi belajar siswa disebabkan oleh pembelajaran fisika masih kurang menarik (Huda, 2013). Pembelajaran fisika dapat menjadi lebih menarik jika dalam pelaksanaannya guru menerapkan metode yang membuat siswa terlibat secara aktif. Salah satu contohnya adalah dengan menerapkan metode eksperimen (Ardhuha, Wahyudi, \& Kosim, 2013). Melalui metode eksperimen siswa dapat belajar secara langsung dari interaksi dengan benda-benda yang digunakan dalam kegiatan tersebut (Widiyanto, 2011). Fungsi dari eksperimen itu sendiri adalah sebagai penunjang pembelajaran guna meningkatkan pemahaman siswa terhadap materi yang telah dipelajari (Salam, Setiawan, \& Hamidah, 2010).

Berdasarkan hasil observasi diperoleh informasi bahwa kegiatan eksperimen untuk materi listrik dinamis jarang dilaksanakan karena alat yang 
tersedia di laboratorium terbatas. Terkait dengan hal tersebut, kegiatan eksperimen dapat dilaksanakan walau tanpa adanya alat-alat praktikum seperti biasanya, yang disebut eksperimen virtual (Lesmono et al, 2012). Hal ini dapat dilakukan dengan memanfaatkan laboratorium virtual berbantuan teknologi komputer (Agustine, Wiyono, \& Muslim, 2014; Hafsyah, Prihandono, \& Yushardi, 2012)

Eksperimen virtual ialah eksperimen dengan memanfaatkan media virtual seperti simulasi komputer atau media laboratorium virtual, sehingga kegiatan ini dapat dijadikan sebagai salah satu solusi untuk mengatasi keterbatasan prasarana laboratorium (Sutarno, 2013; Gunawan, Harjono, \& Sutrio, 2015).

Sesuai dengan permasalahan yang telah dijabarkan di atas, maka tujuan penelitian ini adalah untuk mengetahui pengaruh penerapan metode pembelajaran fisika berbasis eksperimen virtual terhadap motivasi dan hasil belajar fisika siswa kelas X MAN 2 Mataram tahun ajaran 2014/2015.

Hasil penelitian ini diharapkan dapat bermanfaat bagi pengembangan metode pembelajaran dalam mata pelajaran fisika serta dapat bermanfaat bagi guru, siswa, peneliti, pembaca, dan lembaga pendidikan yang ingin mengambil kajian yang sama untuk meningkatkan hasil belajar fisika siswa.

\section{TINJAUAN PUSTAKA}

\section{A. Pembelajaran Fisika}

Pembelajaran merupakan suatu proses belajar mengajar untuk mencapai tujuan pembelajaran atau hasil belajar. Pembelajaran dilakukan oleh guru sebagai pengajar dan siswa sebagai subjek belajar (Sardiman, 2010). Agar memperoleh hasil yang optimal, proses pembelajaran ini harus dilakukan secara sadar dan sengaja serta terorganisasi secara baik.

Terdapat tiga konsep pembelajaran, yaitu (1) pembelajaran bersifat psikologis, pembelajaran sebagai proses interaksi antara individu dengan lingkungan sekitarnya, dan (3) pembelajaran sebagai produk dari interaksi dengan lingkungan sekitarnya (Huda, 2013). Komponen-komponen yang mempengaruhi pembelajaran yang dimaksud adalah guru, siswa, tujuan, materi pelajaran, model atau metode pembelajaran, sarana dan prasarana yang tersedia, serta evaluasi hasil pembelajaran (Husein, Herayanti, \& Gunawan, 2015).

Pembelajaran fisika merupakan proses belajar mengajar untuk mencapai tujuan dan hasil belajar fisika. Selanjutnya, dalam pembelajaran fisika, terdapat beberapa unsur yang harus dijadikan pertimbangan dalam merancang kegiatan pembelajaran. Unsur-unsur tersebut mencakup rasa ingin tahu, metode ilmiah, fakta, teori, dan aplikasi. Pembelajaran akan lebih baik jika siswa mengalami atau melakukan kegiatan belajar secara langsung, segingga pembelajaran tidak bersifat verbalistrik (Sardiman, 2010). Oleh karena itu, dalam pembelajaran fisika dibutuhkan suatu model atau metode yang membuat siswa terlibat lebih aktif dalam pembelajaran (Lesmono et al, 2012) dan mampu melatih siswa untuk menemukan pengetahuannya secara mandiri (Herayanti \& Habibi, 2015), yaitu dengan menerapkan metode eksperimen (Sumargo \& Yuanita, 2014).

\section{B. Metode Pembelajaran Fisika Berbasis Eksperimen Virtual}

Materi listrik dinamis termasuk salah satu materi fisika yang lebih cocok jika disampaikan dengan menerapkan metode eksperimen (Salam et al, 2010). Metode ini memungkinkan siswa belajar secara langsung melalui interaksi dengan alat-alat yang digunakan dalam kegiatan eksperimen. Namun demikian, metode ini umumnya memerlukan waktu yang cukup lama sehingga variasi kegiatan yang bisa dilakukan relatif sedikit.

Kegiatan eksperimen ini tidak terlepas dari tersedianya laboratorium dan peralatan serta bahan-bahan yang akan digunakan selama kegiatan berlangsung. Namun, kegiatan ini terkendala oleh keterbatasan peralatan eksperimen yang tersedia, seperti alat yang tidak lengkap atau rusak. Meskipun demikian, kegiatan eksperimen tetap dapat dilaksanakan tanpa adanya alat-alat praktikum seperti biasanya (Lesmono et al, 2012). Perkembangan teknologi komputer saat ini memberikan peluang untuk mengembangkan inovasi-inovasi yang dapat membantu proses pembelajaran menjadi leih optimal (Gunawan et al, 2015). Kegiatan eksperimen ini dapat dilakukan dengan 
memanfaatkan laboratorium virtual berbantuan komputer.

Kegiatan eksperimen dengan menggunakan laboratorium virtual ini disebut sebagai eksperimen virtual. Eksperimen virtual merupakan eksperimen dengan memanfaatkan media laboratorium virtual (Sutarno, 2013). Pendapat lain juga menyatakan bahwa eksperimen virtual adalah kegiatan eksperimen yang menggunakan software dan komputer dalam menjalankan fungsi-fungsi penting laboratorium sebagaimana layaknya eksperimen riil (Sarini, 2012). Dengan tersedianya laboratorium virtual ini, maka kegiatan eksperimen virtual dapat dilaksanakan. Kegiatan eksperimen virtual ini dapat menjadi pilihan bagi guru ketika sarana dan prasarana laboratorium terbatas atau tidak lengkap (Arianti, Sahidu, Harjono, \& Gunawan, 2016; Gunawan; Liliasari, 2012).

Penerapan metode pembelajaran fisika berbasis eksperimen virtual memiliki lima tahapan, yaitu mengidentifikasi masalah, merumuskan hipotesis, mengumpulkan data, menganalisis data dan menguji hipotesis, serta menarik kesimpulan. Penerapan metode pembelajaran fisika berbasis eksperimen virtual ini diharapkan dapat memusatkan perhatian siswa (Sarini, 2012), memfokuskan proses belajar pada materi yang sedang dipelajari, membuat proses pembelajaran lebih menarik (Martínez, Naranjo, Pérez, \& Suero, 2011; Sumargo \& Yuanita, 2014), merangsang siswa untuk aktif (Husein et al, 2015; Widiyanto, 2011), dan menjadikan siswa mampu menyesuaikan teori yang dipelajari dengan kenyataan di dalam kehidupan sehari-hari (Salam et al, 2010), serta memberikan pengalaman yang lebih melekat kepada siswa sebagai suatu hasil dari proses pembelajaran.

\section{Motivasi Belajar}

Motivasi berasal dari kata motif. Kata motivasi diartikan sebagai suatu keadaaan dalam diri seseorang yang membangkitkan, memelihara, dan mengarahkan tingkah laku menuju suatu tujuan. Pengertian motivasi tidak dapat dipisahkan dari motif dan kebutuhan. Seseorang yang melakukan sesuatu, sedikit banyaknya ada kebutuhan yang ingin dicapainya. Oleh karenanya, motivasi merupakan suatu variabel yang digunakan untuk membangkitkan, mengelola, mempertahankan, dan menyalurkan tingkah laku menuju suatu tujuan.

Motivasi merupakan salah satu faktor psikologis yang dapat mempengaruhi kegiatan pembelajaran (Sardiman. 2010). Motivasi merupakan usaha yang dilakukan individu untuk mencapai prestasi diri atau dorongan untuk mencapai keberhasilan (Doyan, 2015). Dalam proses belajar, motivasi sangat penting, sebab seseorang tidak mungkin belajar tanpa adanya motivasi belajar. Motivasi belajar berasal dari dalam dan dari luar diri siswa. Motivasi yang berasal dari dalam diri siswa merupakan motivasi intrinsik, sementara motivasi yang berasal dari luar diri siswa merupakan motivasi ekstrinsik.

Motivasi instrinsik didasari oleh kebutuhan dan keinginan dari dalam diri siswa antara lain kebutuhan untuk beraktivitas (belajar), kebutuhan untuk menyenangkan orang lain, kebutuhan untuk mencapai hasil, dan kebutuhan untuk mengatasi kesulitan yang dihadapinya saat ini ataupun nanti (Sardiman. 2010). Motivasi ekstrinsik didasari oleh respon yang berasal dari luar diri siswa atas tingkah lakunya berupa pujian, penghargaan, hukuman, dan kritik. Motivasi dapat tumbuh karena adanya keinginan yang kuat dari dalam diri siswa itu sendiri, serta dapat dirangsang dari luar atau dari orang lain. Motivasi dari luar diri siswa ini dapat berupa penghargaan, hukuman konstruktif, atau lingkungan belajar yang menarik dan menyenangkan.

\section{Hasil Belajar}

Hasil belajar adalah kemampuankemampuan yang dimiliki siswa setelah melakukan belajar. Hasil belajar perlu dievaluasi untuk melihat apakah tujuan pembelajaran yang ditetapkan telah tercapai dan apakah proses belajar mengajar telah berlangsung efektif untuk memperoleh hasil belajar (Sahidu, 2013). Dalam proses evaluasi tersebut, siswa diberi beberapa tes di akhir proses belajar. Penggunaaan tes ini dimaksudkan untuk mendapatkan data tentang hasil belajar yang telah dicapai siswa. 
Hasil belajar digolongkan ke dalam tiga ranah yaitu ranah kognitif (pengetahuan), ranah afektif (sikap), dan ranah psikomotor (keterampilan). Hasil belajar ranah kognitif mencagkup pengetahuan hafalan, pemahaman, penerapan (aplikasi), analisis, sintesis dan evaluasi (Imran, Harjono, \& Gunawan, 2015). Hasil belajar ranah afektif mencakup sikap, kemampuan dan penguasaan segi-segi emosional, yaitu perasaan dan nilai. Selanjutnya, hasil belajar ranah psikomotorik mencakup keterampilan-keterampilan atau gerakan-gerakan fisik.

\section{METODE PENELITIAN}

Penelitian ini merupakan penelitian eksperimen yaitu penelitian yang memberikan perlakuan khusus terhadap variabel-variabel yang diteliti untuk mengetahui ada tidaknya pengaruh atau hubungan sebab akibat dari perlakuan yang diterapkan. Penelitian ini dilaksanakan mulai bulan November 2014 sampai dengan Juni tahun 2015 bertempat di MAN 2 Mataram. Terdapat tiga variabel yang menjadi fokus penelitian yaitu variabel bebas, variabel terikat, dan variabel kontrol. Variabel bebas dalam penelitian ini adalah metode pembelajaran fisika berbasis eksperimen virtual. Variabel terikat dalam penelitian ini adalah motivasi dan hasil belajar fisika siswa. Variabel kontrol dalam penelitian ini antara lain materi ajar, guru, instrumen penilaian, dan alokasi waktu pembelajaran yang dikondisikan sama.

Desain penelitian menggunakan post test only control group design yang bertujuan untuk memperoleh perbedaan hasil belajar fisika antara kelas eksperimen dan kontrol, sehingga pada akhirnya didapatkan pengaruh dari metode pembelajaran yang digunakan. Adapun teknik pengambilan sampel yang digunakan adalah purposive sampling. Melalui teknik ini didapat dua kelas yang terpilih dengan beberapa pertimbangan peneliti (Setyosari, 2013), yaitu kelas X 3 sebagai kelas eksperimen dan kelas X 5 sebagai kelas kontrol, dengan pertimbangan kedua kelas memiliki kemampuan awal yang homogen.

Prosedur dan langkah-langkah yang digunakan dalam melaksanakan penelitian ini mengikuti langkah-langkah pada model pembelajaran inkuiri dan metode pembelajaran konvensional.
Permasalahan yang dikaji dalam penelitian ini adalah motivasi dan hasil belajar fisika siswa. Perlakuan berupa metode pembelajaran fisika berbasis eksperimen virtual diberikan pada siswa kelas eksperimen dan metode pembelajaran konvensional pada siswa kelas kontrol, pada materi listrik dinamis.

Data motivasi dan hasil belajar fisika siswa diperoleh dengan menggunakan instrumen yang telah melalui validasi ahli dan empiris. Instrument berupa lembar observasi dan angket motivasi melalui validasi ahli, sementara tes hasil belajar melalui validasi ahli dan empiris. Berdasarkan hasil uji coba diperoleh 23 soal yang baik untuk digunakan sebagai tes hasil belajar siswa. Analisis data menggunakan uji-t dua pihak polled varians dengan derajat kebebasan $(\mathrm{dk}) \mathrm{n}_{1}+\mathrm{n}_{2}-2$ untuk hipotesis pertama dan $\mathrm{dk}=\mathrm{n}_{1}-1$ untuk hipotesis kedua.

\section{HASIL DAN PEMBAHASAN}

Penelitian ini merupakan penelitian eksperimen yang dilaksanakan untuk mengetahui pengaruh penerapan metode pembelajaran fisika berbasis eksperimen virtual terhadap motivasi dan hasil belajar fisika siswa kelas X MAN 2 Mataram tahun ajaran 2014/2015. Dalam penelitian ini terdapat dua kelas yang digunakan sebagai sampel yaitu kelas eksperimen yang diberi perlakuan berupa metode pembelajaran fisika berbasis eksperimen virtual dan kelas kontrol yang diberi perlakuan pembelajaran fisika konvensional. Dalam pembahasan ini akan dijabarkan hasil analisis data penelitian yang diperoleh berupa nilai ujian tengah semester genap fisika sebelum penelitian sebagai data kemampuan awal siswa, serta data hasil penelitian berupa data motivasi dan hasil belajar (post test) siswa pada kelas eksperimen dan kelas kontrol.

Pada awal penelitian, peneliti menggunakan data nilai hasil ujian tengah semester genap untuk mengetahui apakah kedua kelas memiliki kemampuan belajar yang homogen. Berdasarkan hasil uji homogenitas, diketahui bahwa kemampuan awal siswa antara kelas eksperimen dan kelas kontrol sama atau homogen. Sementara itu, data motivasi dan hasil belajar fisika digunakan untuk mengetahui perbedaan motivasi dan hasil belajar siswa pada ranah kognitif antara kelas eksperimen yang mendapat perlakuan berupa metode pembelajaran fisika berbasis eksperimen virtual dan kelas kontrol 
yang mendapat perlakuan pembelajaran secara konvensional.

Pemberian angket dan tes hasil belajar (post test) dilakukan setelah siswa mengikuti proses pembelajaran pada materi listrik dinamis. Data yang diperoleh dalam penelitian ini berupa data motivasi dan data hasil belajar fisika siswa kelas eksperimen dan kelas kontrol.
Data yang diperoleh dari kedua kelas terdistribusi normal dan homogen. Selanjutnya data motivasi dan hasil belajar fisika siswa tersebut dianalisis dengan menggunakan uji-t dua pihak untuk menguji hipotesis penelitian. Adapun hasil rekapitulasi data motivasi dan hasil belajar pada kelas eksperimen dan kelas kontrol pada materi listrik dinamis disajikan pada Tabel 1. berikut.

Tabel 1. Rekapitulasi Data Motivasi dan Hasil Belajar Siswa pada Kelas Eksperimen dan Kelas Kontrol

\begin{tabular}{lcccc}
\hline \multirow{2}{*}{ Komponen } & \multicolumn{2}{c}{ Data Motivasi } & \multicolumn{2}{c}{ Data Hasil Belajar } \\
\cline { 2 - 5 } & $\begin{array}{c}\text { Kelas } \\
\text { Eksperimen }\end{array}$ & $\begin{array}{c}\text { Kelas } \\
\text { Kontrol }\end{array}$ & $\begin{array}{c}\text { Kelas } \\
\text { Eksperimen }\end{array}$ & $\begin{array}{c}\text { Kelas } \\
\text { Kontrol }\end{array}$ \\
\hline Jumlah siswa & 32 & 32 & 32 & 32 \\
Rata-rata & 78,75 & 68,29 & 78,20 & 64,67 \\
Standar Deviasi & 5,91 & 7,68 & 7,10 & 12,96 \\
Uji Homogenitas & \multicolumn{2}{c}{ Homogen } & \multicolumn{2}{c}{ Tidak homogen } \\
Uji Normalitas & Normal & Normal & Normal & Normal \\
Uji Hipotesis & - t $_{\text {tabel }}>\mathrm{t}_{\text {hitung }}$ atau thitung $>+t_{\text {tabel, }}$, maka $\mathrm{H}_{\mathrm{a}}$ diterima dan $\mathrm{H}_{0}$ ditolak \\
\hline
\end{tabular}

Nilai rata-rata motivasi belajar siswa pada kelas eksperimen dan kelas kontrol yang diperoleh dari angket dan hasil observasi berturut-turut yaitu 78,70 dan 68,29. Hal ini menunjukkan bahwa motivasi belajar siswa pada kelas eksperimen lebih tinggi dari pada siswa pada kelas kontrol. Adanya perbedaan perlakuan yang diberikan pada saat pembelajaran menyebabkan motivasi belajar siswa kelas eksperimen lebih tinggi dibandingkan dengan siswa kelas kontrol.

Nilai rata-rata hasil belajar (post test) siswa pada kelas eksperimen dan kelas kontrol berturutturut yaitu 78,20 dan 64,67. Hal ini menunjukkan bahwa nilai rata-rata siswa kelas eksperimen lebih tinggi dibandingkan dengan nilai rata-rata siswa kelas kontrol. Berdasarkan nilai KKM di MAN 2 Mataram untuk mata pelajaran fisika yaitu 75 , diketahui bahwa nilai rata-rata siswa kelas eksperimen berada di atas KKM, sedangkan nilai rata-rata siswa kelas kontrol berada di bawah KKM. Hal ini terjadi karena adanya perbedaan perlakuan yang diberikan selama proses pembelajaran berlangsung, sehingga nilai rata-rata siswa di kelas eksperimen lebih tinggi dibandingkan dengan kelas kontrol.

Data motivasi dan hasil belajar tersebut dianalisis menggunakan uji-t. Berdasarkan hasil uji normalitas data motivasi belajar pada materi listrik dinamis, pada kelas eksperimen diperoleh nilai $\chi_{\text {hitung }}^{2} 0,6143$ dan $\chi_{\text {tabel }}^{2} 9,488$, sementara pada kelas kontrol diperoleh nilai $\chi_{\text {hitung }}^{2} 3,0342$ dan $\chi_{\text {tabel }}^{2} 9,488$, sehingga data motivasi belajar kedua kelas tersebut terdistribusi normal. Berdasarkan uji statistik parametrik berupa uji-t yang telah dilakukan, diperoleh nilai $t_{\text {hitung }} 14,849$ dan nilai $t_{\text {tabel }} 1,994$, pada taraf signifikan $5 \%$. Kriteria pengambilan keputusan uji-t adalah jika $t_{\text {hitung }}$ lebih besar dari $t_{\text {tabel, }}$ maka $H_{0}$ ditolak dan $H_{a}$ diterima. Hasil perhitungan uji-t menunjukkan bahwa thitung lebih besar dari tabel, sehingga $H_{01}$ ditolak dan $H_{a 1}$ diterima. Dengan demikian, dapat dikatakan bahwa terdapat pengaruh metode pembelajaran fisika berbasis eksperimen virtual terhadap motivasi belajar fisika siswa.

Selanjutnya, berdasarkan hasil uji normalitas data hasil belajar siswa pada kelas eksperimen diperoleh nilai $\chi_{\text {hitung }}^{2} 3,540$ dan $\chi_{\text {tabel }}^{2} 11,030$, sementara pada kelas kontrol diperoleh besar $\chi_{\text {hitung }}^{2}$ 1,489 dan $\chi_{\text {tabel }}^{2} 11,030$, sehingga data hasil belajar pada materi listrik dinamis terdistribusi normal. Berdasarkan uji statistik parametrik berupa uji-t yang telah dilakukan, diperoleh nilai $t_{\text {hitung }} 5,1788$ dan nilai $t_{\text {tabel }} 2,039$, pada taraf signifikan $5 \%$. Kriteria 
pengambilan keputusan uji-t adalah jika thitung lebih besar dari tabel, maka $H_{0}$ ditolak dan $H_{a}$ diterima. Hasil uji-t menunjukkan bahwa nilai $t_{\text {hitung }}$ lebih besar daripada $t_{\text {tabel }}$, sehingga $H_{02}$ ditolak dan $H_{a 2}$ diterima. Dengan demikian, dapat dikatakan bahwa terdapat pengaruh metode pembelajaran fisika berbasis eksperimen virtual terhadap hasil belajar fisika siswa. Kriteria pengambilan keputusan uji-t adalah jika $t_{\text {hitung }}$ lebih besar dari $t_{\text {tabel }}$ atau jika $t_{\text {hitung }}$ lebih kecil dari - $\mathrm{t}_{\text {tabel}}$, maka $\mathrm{H}_{\mathrm{a}}$ diterima dan $\mathrm{H}_{0}$ ditolak. Berdasarkan hasil perhitungan tersebut diperoleh nilai $t_{\text {hitung }}$ lebih besar dari $t_{\text {tabel}}$, sehingga $\mathrm{H}_{\mathrm{a} 1}$ dan $\mathrm{H}_{\mathrm{a} 2}$ diterima. Hasil perhitungan tersebut menunjukan bahwa terdapat perbedaan nilai motivasi dan hasil belajar pada siswa kedua kelas tersebut.

Nilai rata-rata motivasi dan hasil belajar siswa kelas eksperimen lebih tinggi dibandingkan siswa kelas kontrol. Hal ini berarti bahwa terdapat pengaruh positif yang signifikan dari penerapan metode pembelajaran fisika berbasis eksperimen virtual terhadap motivasi dan hasil belajar fisika siswa. Terdapat interaksi positif yang signifikan antara motivasi dan hasil belajar siswa pada kelas eksperimen. Sementara itu, pada kelas kontrol tidak terdapat interaksi yang signifikan antara motivasi dan hasil belajar siswa. Oleh karena itu, dapat dikatakan bahwa metode pembelajaran fisika berbasis eksperimen virtual berpengaruh terhadap motivasi belajar siswa di kelas eksperimen, yang selanjutnya akan mempengaruhi hasil belajar fisika mereka. Metode pembelajaran fisikia berbasis eksperimen virtual mampu meningkatkan motivasi dan hasil belajar siswa.

Berdasarkan hasil yang diperoleh tersebut, metode pembelajaran fisika berbasis eksperimen virtual teruji mampu meningkatkan motivasi dan hasil belajar siswa. Hal ini diperkuat oleh beberapa penelitian sebelumnya. Penelitian sebelumnya yang dilakukan oleh Salam et al (2010) menyatakan bahwa metode eksperimen virtual membuat siswa tertarik untuk mempelajari konsep fisika dengan visualisasi, sehingga mampu meningkatkan motivasi belajar siswa. Penelitian lainnya menyatakan bahwa eksperimen virtual dapat meningkatkan kualitas eksperimen karena memungkinkan untuk diulang berkali-kali (Ariyani, Supawoto, \& Muchlas, 2014). Dengan pengulangan ini, siswa dapat mencapai tujuan eksperimen dengan baik, dan dapat menerapkannya dalam kehidupan sehari-hari. Metode ini membuat siswa tertarik untuk mempelajari konsep fisika dengan visualisasi, sehingga mampu meningkatkan motivasi belajar siswa. Dengan metode ini pula, penguasaan konsep siswa pada materi listrik dinamis meningkat dan membuat pembelajaran fisika menjadi lebih menyenangkan dan memotivasi siswa untuk belajar, yang kemudian mempengaruhi hasil belajar fisika mereka.

Metode eksperimen virtual dapat memudahkan siswa melakukan eksperimen dan memberikan pereduksian waktu pembelajaran. Dengan pereduksian waktu ini guru dapat mengelola dan melaksanakan kegiatan pembelajaran dengan lebih baik dan optimal. Eksperimen virtual juga memberikan ruang kepada siswa untuk mengembangkan kemampuan bereksperimen sesuai dengan imajinasi mereka, tanpa takut akan bahaya ketika melakukan kesalahan saat bereksperimen, seperti salah merangkai komponen listrik, sebagaimana jika melakukan eksperimen biasa. Dengan metode ini, penguasaan konsep siswa pada materi listrik dinamis akan meningkat dan membuat pembelajaran fisika menjadi lebih menyenangkan dan memotivasi siswa untuk belajar, yang kemudian akan mempengaruhi hasil belajar fisika siswa.

Sementara itu, pada pembelajaran konvensional guru menjadi satu-satunya sumber informasi dan perhatian siswa. Siswa akan memperhatikan penjelasan guru di depan kelas, namun tidak semua siswa dapat mengerti penjelasan tersebut. Oleh karena itu, beberapa siswa cenderung menjadi cepat bosan dan pasif selama pembelajaran berlangsung. Hal ini menyebabkan proses pembelajaran menjadi kurang optimal yang kemudian mempengaruhi pencapaian siswa pada hasil belajar fisika siswa.

Perbedaan perlakuan yang diterapkan pada kelas eksperimen dan kelas kontrol mempengaruhi motivasi dan hasil belajar siswa. Selama proses pembelajaran berbasis eksperimen virtual diterapkan di kelas eksperimen, siswa diberikan kesempatan untuk bereksperimen dengan menggunakan program VLabs. Mereka dapat melaksanakan eksperimen secara berkelompok maupun individu di sekolah ataupun di rumah. 
Melalui metode ini, siswa dapat mengembangkan pemahaman dan kreativitas dengan membuat rangkaian listrik sesuai dengan imajinasinya secara virtual. Oleh karena itu, siswa menjadi tertarik dan lebih aktif untuk belajar, sehingga saat pembelajaran berlangsung mereka menjadi lebih antusias dan banyak bertanya mengenai permasalahan yang mereka temukan saat bereksperimen virtual.

Meningkatnya motivasi belajar ini dapat mempengaruhi hasil belajar siswa. Motivasi memiliki peranan yang khas dalam menumbuhkan semangat belajar sehingga tujuan belajar yang ingin dicapai siswa dapat tercapai (Sardiman. 2010). Dalam penelitian ini, metode eksperimen virtual yang diterapkan terbukti mampu meningkatkan motivasi dan hasil belajar siswa kelas eksperimen. Hal ini dapat terlihat dari nilai rata-rata motivasi dan hasil belajar siswa yang lebih tinggi dibandingkan dengan kelas kontrol, serta interaksi positif antara motivasi dan hasil belajar yang signifkan pada kelas eksperimen. Dengan motivasi belajar yang tinggi, siswa kelas eksperimen mampu memperoleh hasil belajar yang tinggi pula.

\section{PENUTUP}

Berdasarkan hasil penelitian dan pembahasan maka dapat ditarik beberapa simpulan, yaitu:

1. Terdapat pengaruh metode pembelajaran fisika berbasis eksperimen virtual terhadap motivasi belajar siswa.

2. Terdapat pengaruh metode pembelajaran fisika berbasis eksperimen virtual terhadap hasil belajar fisika siswa.

Adapun saran yang dapat diberikan agar penerapan metode pembelajaran fisika berbasis eksperimen virtual ini dapat dilaksanakan dengan baik dan lancar, terdapat beberapa hal yang perlu diperhatikan, yaitu:

1. Alokasi waktu diatur sebaik mungkin sehingga tiap tahapan pembelajaran dapat berlangsung secara maksimal;

2. Ketersediaan sarana yang menunjang terlaksananya kegiatan eksperimen virtual, yaitu perangkat komputer atau laptop, yang memadai.

3. Program simulasi dan perangkat komputer disiapkan dengan baik dan sesuai dengan materi yang akan diajarkan.

\section{UCAPAN TERIMA KASIH}

Terima kasih penulis ucapkan kepada bapak $\mathrm{H}$. Mahrup, S. Ag., M. Pd. Selaku kepala MAN 2 Mataram, ibu Rafika Defri, S. Si., ibu Meci Karimah Kasipahu, S. Si., dan bapak Mukarram, S. Pd., selaku guru mata pelajaran fisika, serta seluruh siswa kelas X 3 dan X 5 tahun ajaran 2014/2015 yang telah ikut serta dalam penelitian ini.

\section{REFERENSI}

Agustine, D., Wiyono, K., \& Muslim, M. (2014). Pengembangan e-learning berbantuan virtual laboratory untuk mata kuliah praktikum fisika dasar II di progra studi pendidikan fisika FKI UNSRI. Jurnal Inovasi dan Pembelajaran Fisika, 1(1), 33-42.

Ardhuha, J., Wahyudi, \& Kosim. (2013). Pengembangan panduan praktikum fundamental of physics II sebagai bahan ajar untuk mendukung pelaksanaan praktikum pada program khusus PGMIPABI di FKIP Unram. Jurnal Kependidikan, 12(1), 37-41.

Arianti, B. I., Sahidu, H., Harjono, A., \& Gunawan. (2016). Pengaruh model direct instruction berbantuan simulasi virtual terhadap penguasaan konsep siswa. Jurnal Pendidikan Fisika dan Teknologi, 2(4), 159-163.

Ariyani, R., Supawoto, \& Muchlas. (2014). Pengaruh implementasi virtual lab berbasis multimedia interaktif terhadap pemahaman konsep fisika listrik dinamis. Prosiding Pertemuan Ilmiah XXVIII HFI Jawa Tengah dan DIY (pp. 359352). Yogyakarta: HFI.

Doyan, A. (2015). Penerapan model pembelajaran kuantum pada mata kuliah fisika kuantum ditinjau dari motivasi brprestasi. Jurnal Pendidikan Fisika dan Teknologi, 1(1), 1-8.

Gunawan, Harjono, A., \& Sutrio. (2015). Multimedia interaktif dalam pembelajaran konsep listrik bagi calon guru. Jurnal Pendidikan Fisika dan Teknologi, 1(1), 9-14.

Gunawan, \& Liliasari. (2012). Model virtual laboratory fisika modern untuk meningkatkan disposisi berpikir kritis calon guru. Cakrawala Pendidikan, 31(2), 185-199.

Hafsyah, S. N., Prihandono, T., \& Yushardi. (2012). Penerapan model inkuiri terstruktur dengan media virtual-lab pada pembelajaran fisika di SMP. Jurnal Pembelajaran Fisika, 1(2), 158. 
Herayanti, L., \& Habibi. (2015). Model pembelajaran berbasis masalah berbantuan simulasi komputer untuk meningkatkan keterampilan berpikir kritis calon guru fisika. Jurnal Pendidikan Fisika dan Teknologi, 1(1), 6166.

Huda, M. (2013). Model-model pengajaran dan pembelajaran. Yogyakarta: Pustaka Pelajar.

Husein, S., Herayanti, L., \& Gunawan. (2015). Pengaruh penggunaan multimedia interaktif terhadap penguasaan konsep dan keterampilan berpikir kritis siswa pada materi suhu dan kalor. Jurnal Pendidikan Fisika dan Teknologi, 1(3), 221-225.

Imran, Harjono, A., \& Gunawan. (2015). Efek multimedia pembelajaran pada kemampuan siswa menjawab soal analisis energi pada perubahan wujud air: Sebuah tinjauan pada siswa kelas X SMAN 3 Mataram. Jurnal Pendidikan Fisika dan Teknologi, 1(1), 4751.

Lesmono, A. D., Wahyuni, S., \& Fitriya, S. (2012). Pengembangan petunjuk praktikum fisika brbasis laboratorium virtual (virtual laboratory) pada pembelajaran fisika di SMP/MTs. Jurnal Pembelajaran Fisika, 1(3), 272-277.

Martínez, G., Naranjo, F. L., Pérez, Á. L., \& Suero, M. I. (2011). Comparative study of the effectiveness of three learning environments: Hyper-realistic virtual simulations, traditional schematic simulations and traditional laboratory. Phys. Rev. ST Phys. Educ. Res. 7(2), 020111.

Sahidu, H. (2013). Penilaian hasil belajar. Mataram: Arga Puji Press.

Salam, H., Setiawan, A., \& Hamidah, I. (2010). Pembelajaran berbasis virtual laboratory untuk meningkatkan penguasaan konsep pada materi listrik dinamis. Proceedings of The 4th International Conference on Teacher Education (pp. 688-692). Bandung: UPI.

Sardiman. (2010). Interaksi dan motivasi belajar mengajar. Jakarta: Rajawali Pers.

Sarini, P. (2012). Pengaruh virtual experiment terhadap hasil belajar fisika ditinjau dari motivasi belajar siswa SMA Negeri 1 Singaraja. Jurnal Pembelajaran Fisika, 2(2), 109-127.
Setyosari, P. (2013). Mtode penelitian pendidikan dan pengembangan edisi ktiga. Jakarta: Kencana.

Sumargo, E., \& Yuanita, L. (2014). Penerapan media laboratorium virtual (PhET) pada materi laju reaksi dengan model pengajaran langsung. Unesa Journal of Chemical Education, 119133.

Sutarno. (2013). Pengaruh penerapan praktikum virtual berbasis problem solving terhadap kemampuan berpikir kritis mahasiswa. Prosiding Semirata FMIPA Universitas Lampung (pp. 81-89). Lampung: FMIPA Universitas Lampung.

Widiyanto, J. (2011). Penggunaan media berbasis komputer untuk meningkatkan prestasi belajar mahasiswa. Jurnal Pendidikan MIPA, $3(1), 42-46$. 